\title{
Going Back to Show and Tell: Using your Research to Engage Undergraduates
}

\author{
Alexa Roemmich, Lorrayne Serra, and Debra Mauzy-Melitz
}

\author{
University of California Irvine, Developmental \& Cell Biology, 2011 Biological Sciences III, \\ Irvine CA USA 92617-2300 USA \\ (aroemmic@uci.edu;dmauzyme@uci.edu)
}

\begin{abstract}
Smaller community active learning discussion sections are one of the best opportunities for students in a large lecture to practice and master course material. However, graduate students are frequently reluctant to serve as teaching assistants, because they might not know how to structure a discussion or engage students with the material. A solution to this setback is to incorporate graduate student's research into their discussion sections which will engage both TA and students. This solution also gives TAs confidence in developing their own lesson plan. In this workshop, we will demonstrate a sample active discussion for introductory biology undergrads based on a graduate student's research. We provided guidelines for graduate students to consider when planning with their own discussion plan. By the end of this workshop, attendees were able to identify guidelines for simplifying real-world research into modules for undergraduates and create a class activity integrating personal research and course objectives. This activity is best suited for graduate students leading smaller discussions within a larger lecture course (and those who mentor them), but is relevant to anyone who wishes to bring real-world research and experimental data into an introductory course.
\end{abstract}

Keywords: TA training, lesson plans, graduate research

\section{Mission, Review Process \& Disclaimer}

The Association for Biology Laboratory Education (ABLE) was founded in 1979 to promote information exchange among university and college educators actively concerned with teaching biology in a laboratory setting. The focus of ABLE is to improve the undergraduate biology laboratory experience by promoting the development and dissemination of interesting, innovative, and reliable laboratory exercises. For more information about ABLE, please visit http://www.ableweb.org/.

Advances in Biology Laboratory Education is the peer-reviewed publication of the conference of the Association for Biology Laboratory Education. Published articles and extended abstracts are evaluated and selected by a committee prior to presentation at the conference, peer-reviewed by participants at the conference, and edited by members of the ABLE Editorial Board. Published abstracts are evaluated and selected by a committee prior to presentation at the conference.

\section{Citing This Article}

Roemmich A, Serra L, and Mauzy-Melitz D. 2020. Going back to show and tell: using your research to engage undergraduates. Article 52 In: McMahon K, editor. Advances in biology laboratory education. . Volume 41. Publication of the 41st Conference of the Association for Biology Laboratory Education (ABLE). https://doi.org/10.37590/able.v41.abs52

Compilation (C) 2020 by the Association for Biology Laboratory Education, ISBN 1-890444-17-0. All rights reserved. No part of this publication may be reproduced, stored in a retrieval system, or transmitted, in any form or by any means, electronic, mechanical, photocopying, recording, or otherwise, without the prior written permission of the copyright owner.

ABLE strongly encourages individuals to use the exercises in this volume in their teaching program. If this exercise is used solely at one's own institution with no intent for profit, it is excluded from the preceding copyright restriction, unless otherwise noted on the copyright notice of the individual chapter in this volume. Proper credit to this publication must be included in your laboratory outline for each use; a sample citation is given above. 